\title{
DOS ARMÁRIOS NOSSOS DE CADA DIA: UMA (AINDA) PRESENÇA FORMADORA DO(S) ARMÁRIO(S) NO COTIDIANO CONTEMPORÂNEO DO SER LÉSBICA
}

\author{
Carolina Stéphanie Rodrigues Gonçalves ${ }^{1}$ \\ Marta Gouveia de Oliveira Rovai ${ }^{2}$
}

\section{RESUMO}

Neste trabalho teremos o propósito de apresentar e conhecer, a partir das narrativas pessoais (e políticas) de duas mulheres lésbicas estudantes universitárias - colhidas por meio da aplicação do método História Oral de Vida - o(s) "armário(s)" e algumas das facetas do modus operandi desse regime e de suas regras contraditórias e limitantes. Nossa hipótese, dentre outras coisas, é que, como narrativas exemplificativas, as falas das entrevistadas, ainda que involuntariamente, poderão dar testemunho da extensão e força da imagem do(s) armário(s), podendo nos remeter a duas conclusões vitalmente importantes a que chega Eve Sedgwick em A epistemologia do armário: que este ainda é a característica fundamental das vidas que não se enquadram nos marcos heteronormativos, com uma (ainda) forte presença formadora, e que "assumir-se" ou "sair do armário" em alguma(s) das dimensões da vida de uma pessoa "LGBT" não a retira automaticamente do(s) armário(s) que a enredam. Fazendo-o, o campo narrativo dessa investigação intentará aproximar-se de uma agenda de redescrição das práticas de gênero e sexualidade - antilgbtfóbica e anti-sexista - e de questionamento dos privilégios da norma e de sua indiferença para com as pessoas inaudíveis para a ordem androcêntrica e heterossexual, contrabandeando falas subalternizadas (in casu, falas de mulheres lésbicas) para o interior da academia.

Palavras-chave: Armário(s). Lesbianidades. Subjetividade. Cultura heterossexista.

\footnotetext{
${ }^{1}$ Graduanda em Ciências Sociais (Bacharelado) pela Universidade Federal de Alfenas (UNIFAL-MG) e bolsista de Iniciação Científica pelo Programa Institucional de Bolsas de Iniciação Científica (PIBIC/CNPq). E-mail: crln.stephanie@gmail.com

${ }^{2}$ Professora Adjunta de História na Universidade Federal de Alfenas (UNIFAL-MG), pesquisadora do Núcleo de Estudos em História Oral (NEHO/USP), do Núcleo de Pesquisa Cidade, Cultura e Identidade (CCI/UESPI) e do Grupo de Pesquisa História do Brasil: Memória, Cultura e Patrimônio, da UNIFAL. E-mail: marta.rovai@unifal-mg.edu.br

CSOnline - Revista Eletrônica de Ciências Sociais, Juiz de Fora, n. 23 (2017), pp. 327- 343
} 


\section{INTRODUÇÃO}

Em palestra à Associação Moderna de Linguagem, em 1978, Monique Wittig, por meio de sua tese desmistificadora de "contrato heterossexual" - entendido como um aglomerado de ciências e disciplinas, teorias e ideias correntes, a que ela chama de pensamento heterossexual -, reflete sobre a supremacia heteronormativa na realidade social. Aquele servir-se-ia (e continuaria hegemonicamente a se servir) de um sistema de signos (conjunto de mitos heterossexuais), dramatizando as categorias da linguagem, rotulando-as como primitivas e, portanto, menosprezando-as como elementares, se emitidas por pessoas oprimidas.

Desnudemos, a partir dela própria, o rosto "óbvio" do heterossexual e a sistemática heterossexualizadora escamoteada sob a circulação de valores certos $e$ seguros e, tão logo, merecedores de devoção e investimentos contínuos como na e pela antropologia, psicanálise, mas bem como em todas as ciências sociais.

\footnotetext{
Com a sua inescapabilidade erigida em conhecimento, em princípio óbvio, em dado pré-adquirido a qualquer ciência, o pensamento hétero desenvolve uma interpretação totalizante da história, da realidade social, da cultura, da linguagem e simultaneamente de todos os fenômenos subjetivos. Posso apenas sublinhar o caráter opressivo de que se reveste o pensamento hétero na sua tendência para imediatamente universalizar a sua produção de conceitos em leis gerais que se reclamam de ser aplicáveis a todas as sociedades, a todas as épocas, a todos os indivíduos. Assim, fala-se de conceitos como a troca de mulheres, a diferença entre os sexos, a ordem simbólica, o Inconsciente, Desejo, [...] Cultura, História, dando um significado absoluto a estes conceitos, quando são apenas categorias fundadas sobre a heterossexualidade, ou sobre um pensamento que produz a diferença entre os sexos como um dogma político e filosófico.

[...] A retórica que expressa estes processos (e cuja sedução eu não subestimo) reveste-se de mitos, recorre ao enigma, caminha pelo acumular de metáforas, e a sua função é a de poetizar o caráter obrigatório do "seráshetero-ou-não-serás" (WITTIG, 2005, p. 51-52).
}

Assim, o que provocativamente fora colocado pela novelista e teórica feminista lésbica em 1978, a saber: o poder do pensamento straight e o modo como ele afeta todas as pessoas (o modo como agem, se movem, e, é claro, pensam), pareceu-nos ser útil para pensarmos o registro discriminatório e injusto produzido pelo marco heterononormativo. Isto é: como, no desenvolvimento da ciência, prevaleceria a não percepção daqueles sujeitos que não figuram como os sujeitos hegemônicos da representação, e como aquela se desinteressaria e também não se aperceberia em relação aos fenômenos, teorias e problemas colocados por essas vidas humanas reputadas como 
"abjetas", por localizarem-se fora das estreitas faixas de problemas ("esotéricos") sobre as quais se concentram os cientistas. Não só frequentemente são vidas não vistas pelas estruturas sociais e epistêmicas, como frequentemente, quando tentam subverter suas invisibilidades promovendo fissuras epistêmicas, não são toleradas. Ou seja, dito de forma mais clara, a ordem epistêmica paradigmática, não só, mas também, sustenta a violência e subalterniza as formas de experiência do corpo e da sexualidade fora da cisgeneridade e da heteronormatividade. "Os assassinatos, espancamentos e insultos sexistas e homo[lesbo/bi/pan/trans]fóbicos são gestados em um horizonte epistêmico específico, em que um modo de inteligibilidade dos corpos e da vida se afirma" (OLIVEIRA; DINIZ, 2014, p. 248-149). Assim, as vidas travestis, transexuais, transgêneras, lésbicas, gays, pansexuais, bissexuais, assexuais, intersexuais e queers, não figuram nas paisagens epistemológicas hegemônicas (ou quando muito, sempre como extremamente e incomodamente visíveis), sendo-lhes, assim, retirado o direito à existência plena.

Debaixo de um discurso de "universalidade" e "neutralidade" do conhecimento produzido, disfarça-se, pois, suas referências (silenciosas mas não menos evidentes): a heterossexualidade e o diferencialismo de gênero, a partir dos quais mundos são binariamente performados.

\begin{abstract}
O marco epistêmico da heteronormatividade é um dispositivo hierarquizante cujas regras naturalizantes (tidas como autoevidentes) tornam o que a elas escapa um erro, uma exceção, uma abjeção. Esse sistema de inteligibilidade é o horizonte sobre o qual emergimos como sujeitos, e em que aprendemos a sentir, pensar, falar, existir. Esse marco rege a inteligibilidade dos corpos, estabelece o que é cognoscível, condiciona as formas de reconhecimento dos corpos por meio de características que serão consideradas óbvias, visíveis e, até mesmo, presumíveis. Os marcos epistêmicos são normas de inteligibilidade, são esquemas de percepção pelos quais conhecemos um corpo e pelos quais reconhecemos os modos de vida considerados naturais ou normais. Se a heteronormatividade coloniza os modos de representação [...] [da estrutura do conhecimento como um todo], as paisagens curriculares [por exemplo] não ensinam que corpos e subjetividades podem ser vividos e pensados de outras maneiras, isto é, fora dessa norma (OLIVEIRA; DINIZ, 2014, p. 249-250).
\end{abstract}

Um campo epistemológico contaminado por marcos normatizantes revela-se, pois, em seu sentido violento: a implementação de um mutismo, ou seja, um brutal regime de silenciamento das vozes subalternizadas. As demandas, perspectivas e potências políticas de corpos de sujeitos hegemônicos podendo se expressar e dispondose à atenção, no âmbito acadêmico, e a de corpos dos sujeitos "diferenciais" não podendo sê-las ou, quando sendo, limitadas, redundando em neutralização e 
invisibilidade. Com a territorialização da boca e o interdito da fala (que a acompanha para alguns sujeitos, os não-hegemônicos), desenrolam-se debaixo de nossas vistas o controle sobre o mundo conceitual e a construção de um regime de "verdade". O que essa territorialização intenta é tornar uma fala "a" verdadeira e o faz por meio da inviabilização da manifestação daquelas que venham em sentido contrário.

\begin{abstract}
Assim é que, no marco [heteronormativo], o sujeito [hétero] depende da produção arbitrária do sujeito [homossexual] como "Outro" silenciado para se constituir, atualizando, a partir do binômio [hétero/homo], uma série de outras fórmulas binárias tais como bem/mal, certo/errado, humano/inumano, racional/selvagem, nas quais o [homossexual] não cessa de ser representado como mal, errado, inumano, selvagem. Dessa maneira, não é jamais o sujeito [homossexual] que está em questão, mas as imagens e narrativas dominantes produzidas desde um ponto-de-vista colonial acerca dele (MOMBAÇA, 2015, on-line).
\end{abstract}

Assim, os regimes de produção do saber acadêmico são, como visto, batizados e caracterizados por um marco epistemológico por inteiro colonizado e contaminado por silenciamentos, desinteresses e limitações. Em uma operação dissimulada, procura-se, em verdade, "[...] definir que conhecimentos são reconhecidos enquanto tal e quais não; que conhecimentos compõe a agenda acadêmica; quem pode ser reconhecido ou não como detentor de conhecimento; quem pode ensinar; e, no limite, quem pode falar" (MOMBAÇA, 2015, on-line).

Como o espaço acadêmico é entendido como possível espaço de violência e com poderosa energia silenciadora de corpos e resistências LGBT's, invariavelmente ocupando-se em subalternizar os sujeitos não-hegemônicos de gênero e sexualidade bem como suas formas desviantes de produzir saber, e porquanto o entendamos assim, para além de reconhecermos esta economia política de produção de conhecimentos, intentamos quebrantá-la em alguma medida.

Neste diapasão, inserindo-se em uma agenda de direitos humanos capitaneada pela promoção da equidade, estas páginas assumem as questões de gênero e sexualidade e a necessidade de criar condições para o reconhecimento da diversidade e para o combate dos vários modos de precarização e subalternização das vidas de mulheres e pessoas LGBT's. Recusa-se, pois, os modos de representação e figuração sobre gênero e sexualidade longamente impostos pelos espaços tradicionalmente conservadores. Ao recusá-los, o que nos moveu como nosso principal desafio ético foi a desconstrução do marco da heteronormatividade.

O que temos assistido nos domínios acadêmicos, como nos espaços das Ciências Sociais, mas não só nestes, é que cada vez mais passa-se a receber um maior número de CSOnline - Revista Eletrônica de Ciências Sociais, Juiz de Fora, n. 23 (2017), pp. 327- 343 
estudantes lésbicas, gays, bissexuais, pansexuais, pessoas transexuais, travestis, etc., ávidos por compreenderem as estruturas heteronormativas e cisgêneras e a dominação masculinista, por exemplo, a partir das teorias de gênero e sexualidade. Por nos situarmos nessa geração interessada em romper, em alguma medida, com o silêncio longamente imposto diante das questões de gênero e sexualidade, queremos aqui repensar as vidas humanas que não se enquadram nesses marcos normativos, "[...] de modo que as vidas que não são tornadas visíveis em sua vulnerabilidade, precariedade ou necessidade de proteção sejam objeto de atenção" (OLIVEIRA; DINIZ, 2014, p. 242).

Teremos, para tanto, o propósito de apresentar e (tentar) conhecer, a partir das geografias pessoais (e políticas) de duas mulheres lésbicas estudantes universitárias colhidas por meio da aplicação do método História Oral de Vida - o(s) "armário(s)" e algumas das facetas do modus operandi desse regime e de suas regras contraditórias e limitantes. Nossa hipótese, dentre outras coisas, é que, como narrativas exemplificativas, as falas das entrevistadas, ainda que involuntariamente, poderão dar testemunho da extensão e força da imagem do(s) armário(s), podendo nos remeter a duas conclusões vitalmente importantes a que chega Eve Kosofsky Sedgwick em "A epistemologia do armário": i) "[...] há poucas pessoas gays, por mais corajosas e sinceras que sejam de hábito, por mais afortunadas pelo apoio de suas comunidades imediatas, em cujas vidas o armário não seja ainda uma presença formadora" (SEDGWICK, 2007, p. 22, grifo nosso); e ii) "[a]ssumir-se não acaba com a relação de ninguém com o armário, inclusive, de maneira turbulenta, com o armário do outro" (SEDGWICK, 2007, p. 40, grifo nosso).

Além desta introdução, que conta com a apresentação do tema e justificativa, o trabalho é composto por mais três seções, sendo a última referente às considerações finais. Na primeira seção, é feita uma discussão sobre as dificuldades e facilidades da entrada e inserção no campo - trata-se, provocativa e metaforicamente, de nossa "entrada" no armário. A segunda seção apresenta fragmentos de duas entrevistas feitas com jovens mulheres lésbicas universitárias. A partir delas, é possível refletir sobre a relação entre lesbianidades e saída(s) do(s) armário(s). Estaremos, aqui, em um segundo movimento, "dentro" do armário. Por fim, nas considerações finais - fraseadas como "'saindo' do armário?", retomamos os pontos centrais de reflexão das seções anteriores.

Contra essa retirada de direitos, o campo narrativo dessa investigação intentará aproximar-se de uma agenda de redescrição das práticas de gênero e sexualidade - anti- 
lgbtfóbica e antissexista - e de questionamento dos privilégios da norma e de sua indiferença para com as pessoas subalternizadas pela ordem androcêntrica e heterossexual, contrabandeando falas subalternas (in casu, falas de mulheres lésbicas) para o interior da academia.

\section{1 "Entrando" no armário: as tentativas de inserção no campo}

Esta seção problematiza a movimentação da autora (principal) deste trabalho no que concerne a sua entrada e inserção no campo, a partir de suas dificuldades. Logo, advertimos os(as) leitores(as) que sua escrita se dará em primeira pessoa e a partir da ótica somente de uma das autoras, sobre a qual já fizemos menção.

Inicialmente, dois critérios foram estabelecidos para a escolha das interlocutoras: serem mulheres que se auto-referenciam como lésbicas ${ }^{3}$; e terem participado da (terceira) roda de conversa "LGBT" do "Projeto (R)Existo" - um projeto autoorganizado por graduandos(as) de aceitação, acolhimento, identificação, empatia e apoio aos LGBT's da Universidade Federal de Alfenas (UNIFAL-MG) e de Alfenas -, que ocorre aos domingos (das 19h às 21h) em sala de aula (Prédio V, Sala V301) do espaço físico da referida universidade.

Duas mulheres despontaram como duas possíveis interlocutoras: a primeira, quando da terceira roda de conversa "LGBT", auto-referenciou-se, no início da roda de conversa, como mulher lésbica e negra, e fora identificada por mim como a principal liderança feminina do Projeto. A segunda, por ter se responsabilizado pela formação ${ }^{4}$

\footnotetext{
${ }^{3}$ Muito embora não desconheçamos que os modos de auto-referencialidades extrapolam categorias fixas e que muitas são as potencialidades de diferenciação e individualização enquanto lésbica, evocamos, aqui, a categoria identitária "lésbicas" tão-somente no plano discursivo (como somente poderia sê-lo, como nos diz Novaes (1993, p. 24)) e por constituir-se, este nós coletivo, em um recurso indispensável do nosso sistema de representações e vital para esse grupo social que o reivindica. "Indispensável porque é a partir da descoberta e reafirmação - ou mesmo criação cultural - de suas semelhanças que um grupo qualquer, numa situação de confronto e de minoria, terá condições de reivindicar para si um espaço social e político de atuação" (NOVAES, 1993, p. 24). Evocamo-la, assim, na tentativa de reivindicarmos uma maior visibilidade social para esse grupo, que, historicamente, fora apagado (como brevemente discutido na introdução deste trabalho). Isto posto, ainda que o fenômeno identitário (qualquer que seja ele), ao apropriar-se de uma categoria ampla, como lésbicas in casu, forje uma mesmice e, por conseguinte, desconsidere as diferenças para que possa operar, o faz exatamente para que o espaço político da diferença possa ser evocado, como afirma Novaes (1993, p. 27). E isto foi o que tentamos fazer.

${ }^{4}$ Em entrevista informal, segundo a principal liderança masculina da roda de conversa (por nós identificada e sentida enquanto tal), tratou-se da primeira formação nas rodas de conversa do (R)Existo. $\mathrm{Na}$ mesma entrevista, a liderança em comento disse ter se tratado de uma sugestão de uma jovem mulher, lésbica, estudante universitária da UNIFAL-MG, para contemplar a diferença central entre identidade de gênero e orientação sexual, entendida por ele como a base para um coletivo "LGBT" ser iniciado, o "básico do básico", como nos disse, inclusive para despertar a ideia de um coletivo, o pretenso "Coletivo (R)Existo".
}

CSOnline - Revista Eletrônica de Ciências Sociais, Juiz de Fora, n. 23 (2017), pp. 327- 343 
"LGBT" nomeada "Identidade de Gênero" e por tê-la ministrado, também despontara enquanto tal. Assim, passei a entrar em contato - via redes sociais (facebook) - com estas que seriam duas possíveis interlocutoras para meu trabalho. Por ser uma mulher lésbica e me propor a refletir sobre lesbianidades (o que faz com que eu compartilhe experiências e vivências mais ou menos similares às experenciadas pelas minhas interlocutoras) isso me fez entrar em contato com elas de maneira assaz otimista, ainda que "[seja] fato [...] não [ser] preciso ser lésbica para dizer de lésbicas, mas também [que seja] inegável que muitas vezes [...] esse fator contribui para a efetivação do campo" (SILVA, 2015, p. 34). Mas, infelizmente, não foi o caso aqui. Tão logo eu entrasse em contato, meu otimismo inicial fora desfeito. Expliquemos melhor: como não tinha acesso direto às possíveis interlocutoras, acionei o ciberespaço (in casu, o Facebook) e sua ferramenta de envio de mensagens privadas para chegar até elas, por meio da criação de um grupo privado (no qual as duas possíveis interlocutoras foram por mim adicionadas em um mesmo grupo). Sendo assim, fui a campo, de forma a conseguir fazer meu trabalho, e perquirindo-me sempre sobre a abordagem mais adequada a fazer para que minhas interlocutoras me concedessem entrevistas. Meus primeiros movimentos são ilustrados pelas figuras abaixo:

Figura 1 - Conversa via Facebook com possíveis interlocutoras

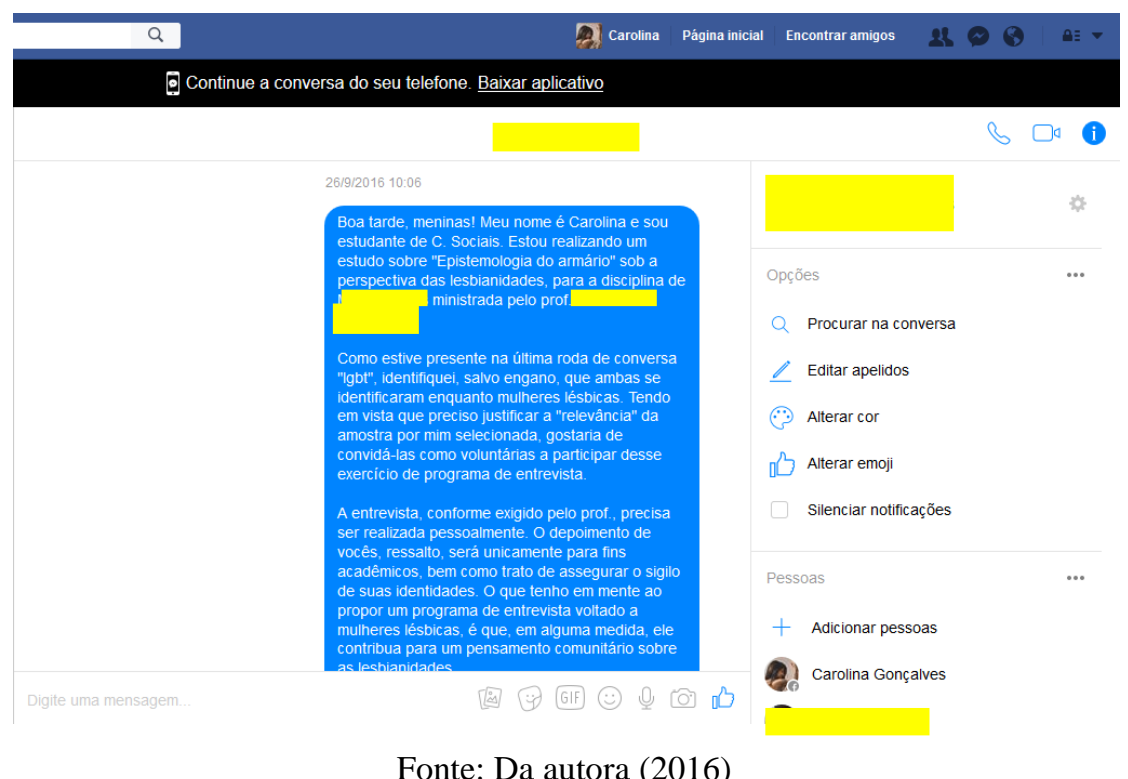

Fonte: Da autora (2016) 
Figura 2 - Continuação

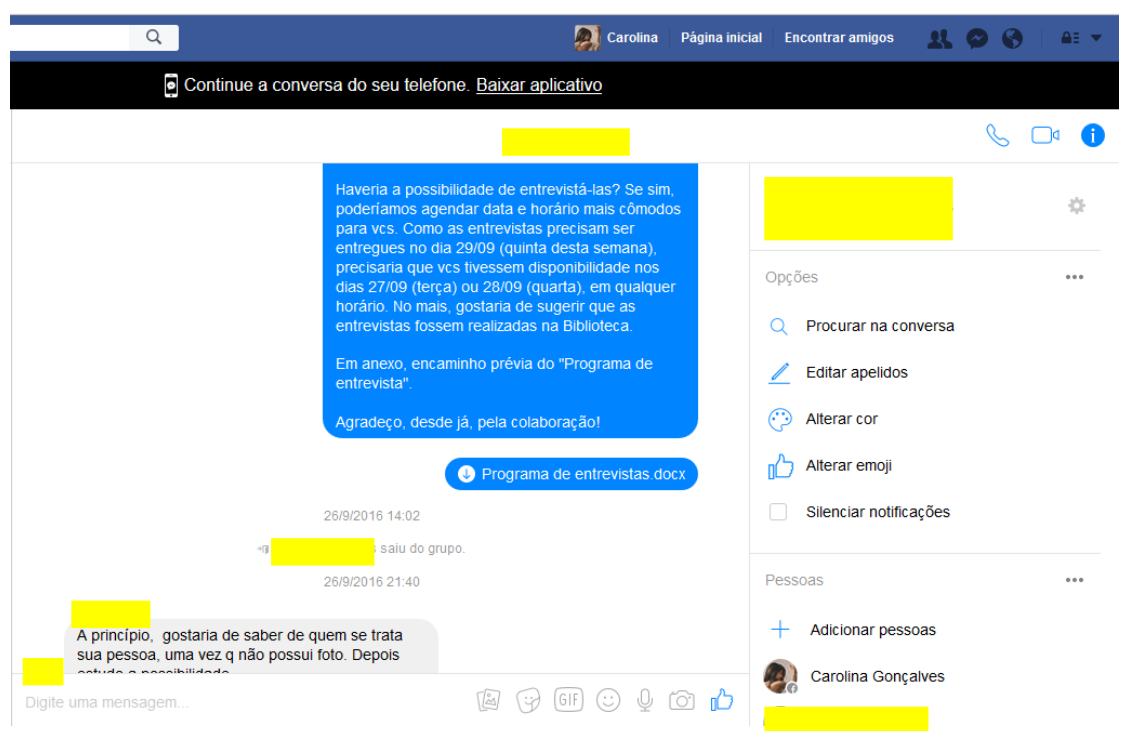

Fonte: Da autora (2016)

Figura 3 - Continuação

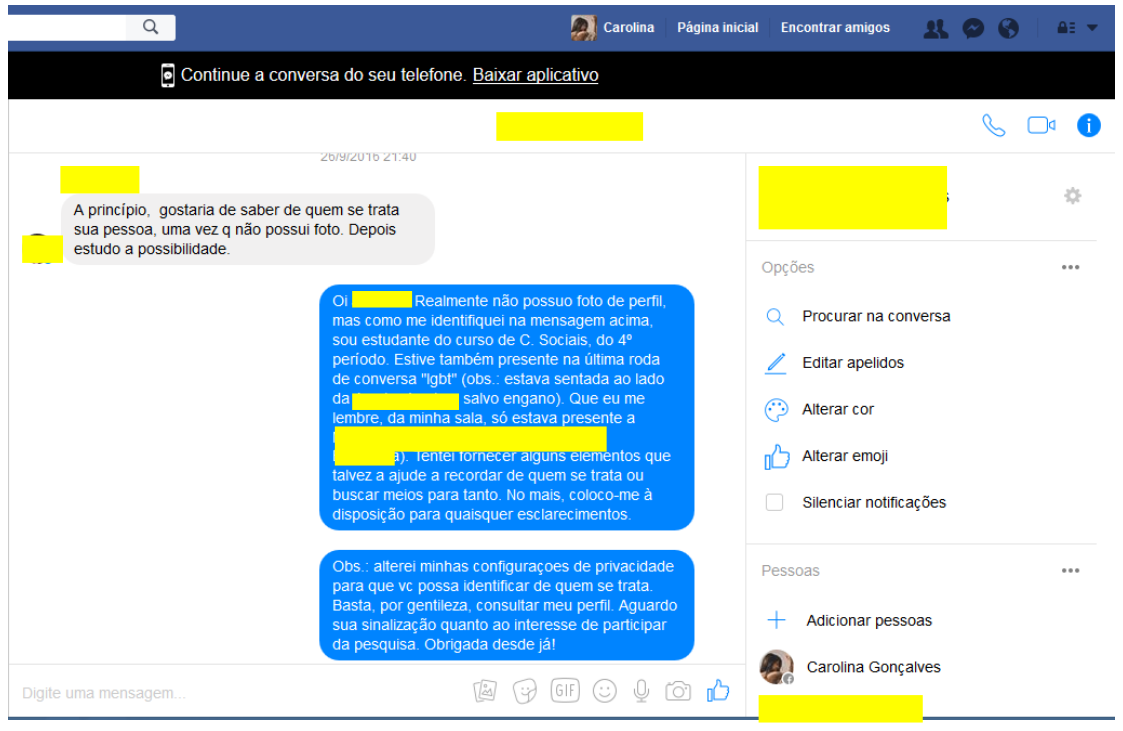

Fonte: Da autora (2016) 
Figura 4 - Continuação

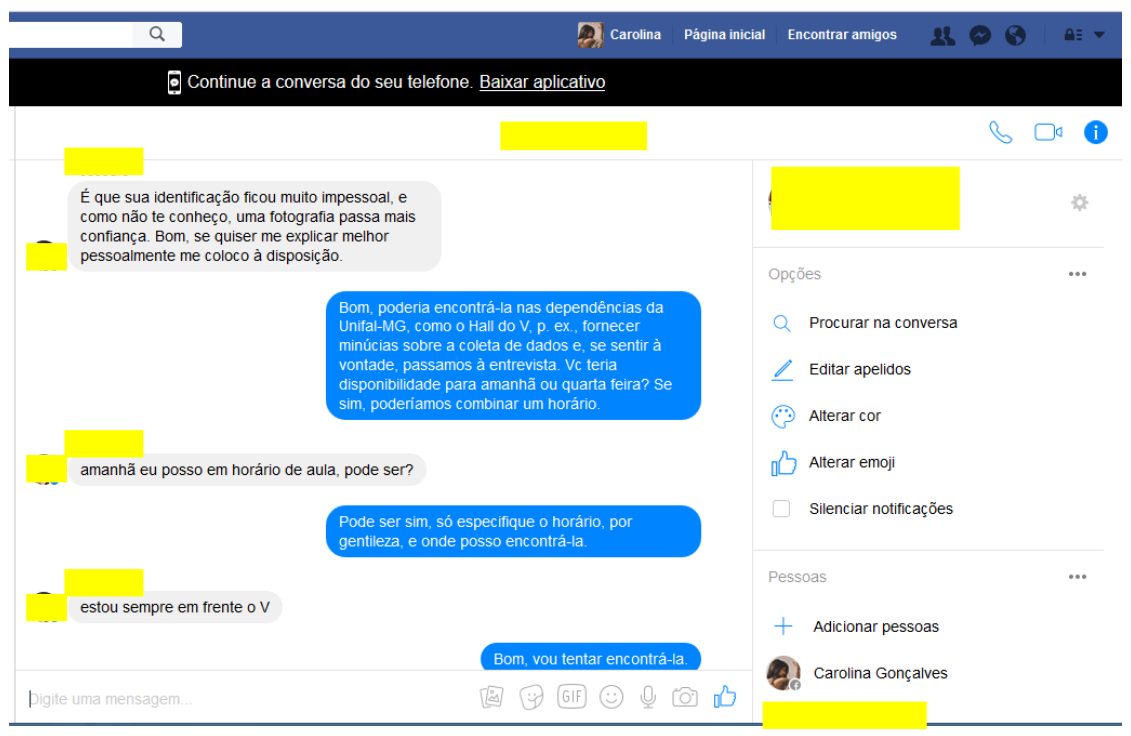

Fonte: Da autora (2016)

As figuras acima mostram minhas dificuldades de inserção no campo: com uma das interlocutoras eu enfrentava uma clara desconfiança em relação a mim, e com a outra interlocutora, uma manifesta recusa em participar da entrevista, explicitada por meio de sua saída do grupo que por mim fora criado (conforme Figura 2), antes mesmo que eu pudesse iniciar, com ela, um contato mais direto. A impessoalidade alegada por uma das interlocutoras foi necessária para mim, porque, confesso, ter tido receio de as mulheres confundirem minhas intenções de pesquisa com algum tipo de interesse afetivo-sexual. Mas, ironicamente, tal receio pode ter feito, dentro outros motivos (como minha opção particular por não manter à época uma foto de perfil em meu Facebook), com que um afastamento e uma resistência fossem gerados em minhas potenciais interlocutoras. Assim, e em situação semelhante à descrita por Silva (2015, p. 30), "[e]ntrei em contato com várias mulheres e todas elas demonstraram 
disponibilidade, que nunca foi concretizada. E assim meu campo foi marcado por vários 'nãos' no formato de 'sim'".

Uma vez que minha primeira movimentação em campo não resultara em minha inserção, parti, então, para minha rede social pessoal para o estabelecimento de contato com outras novas possíveis interlocutoras. Agora, já mantendo apenas o primeiro dos três critérios para a escolha de interlocutoras (qual seja, que fossem mulheres que se auto-referenciassem como lésbicas), optei, deste modo, por abordar colegas/ amigas/ conhecidas perguntando se elas possuíam disponibilidade para me concederem entrevista. A partir dessa segunda movimentação, conseguimos alcançar duas novas interlocutoras, que se mostraram completamente disponíveis para participarem de entrevistas para o nosso trabalho, o que nos permitiu refletir sobre diversas questões ligadas às vivências e às percepções das lesbianidades e, máxime, pensar sobre nosso tema de interesse - a(s) saída(s) do(s) armário(s) - a partir dali, construindo algumas reflexões a partir da vivência relatada por nossas interlocutoras. Assim, passamos a dialogar com as interlocutoras que tinham se mostrado disponíveis.

\section{2 "Dentro" do armário}

Uma vez tendo discutido as dificuldades e posteriores facilidades de inserção em campo e o desenvolvimento do contato com nossas interlocutoras, passamos a dialogar com aquelas que tinham se mostrado disponíveis, a partir de nossa segunda movimentação no campo. A intenção foi de ouvir, em um primeiro momento, suas histórias de vida sob o ponto de vista de suas lesbianidades: como e quando elas tinham se percebido como lésbicas, como tinha e tem sido suas relações com as pessoas das suas famílias e dos seus ambientes de estudo ou de trabalho, e também com seus amigos. A entrevista foi semi-estruturada e teve como pontapé inicial esta pergunta 5 . Como nós estávamos investigando a(s) saída(s) do(s) armário(s), sendo esta nossa temática central, outras perguntas ${ }^{6}$ foram por nós mobilizadas. Ademais, esse trabalho adota nomes fictícios para as interlocutoras apresentadas ${ }^{7}$.

5 "Sua vida sob o ponto de vista da homossexualidade. Gostaríamos que você nos contasse suas experiências de vida enquanto lésbica: como e quando você se percebeu lésbica, como foi e tem sido sua relação com as pessoas da sua família e do seu ambiente de estudo ou de trabalho, e também com seus amigos".

6 Como você acha que é lida socialmente como lésbica ou "passa" como heterossexual; quais sentimentos predominam em você sobre sua lesbianidade; quais sentimentos predominam em você sobre a lesbofobia;

CSOnline - Revista Eletrônica de Ciências Sociais, Juiz de Fora, n. 23 (2017), pp. 327- 343 
Mas aqui, antes de prosseguirmos, se deve discernir a relação subjetiva que vai marcar indelevelmente, desde a perspectiva da autora (principal) deste trabalho, sua relação de "pesquisadora" com suas informantes, experiência marcada por sua biografia individual: afinal, como já o dissemos, dialogamos com mulheres lésbicas e uma de nós se identifica como lésbica também. De feito, porquanto nosso trabalho diga sobre os sujeitos que estudamos, também dirá, necessariamente, sobre esta estudantepesquisadora em campo. Assim como "[o]s trobriandeses que conhecemos são aqueles vistos a partir do olhar de Malinowski, um olhar historicamente marcado, sem dúvida, mas também um olhar formado pela história individual do pesquisador" (GROSSI, 1992, p. 8), nossa recentíssima prática de campo (como as entrevistas com mulheres lésbicas), também é dotada de historicidade e subjetividade. Mas, conquanto estejamos, com Grossi (1992), colocando sob o foco dos refletores a subjetividade constitutiva da relação pesquisadora/ pesquisada, em um movimento paradigmático de revalorização desta no contato com o outro e na produção do conhecimento antropológico, cabe advertir, como o faz a autora:

Não proponho transformar a Antropologia em Psicologia e passar a investigar
as neuroses individuais que nos levaram a investigar assuntos como por
exemplo Violência ou Canibalismo, Classes Médias ou Classes
Trabalhadoras, Freiras ou Bruxas. Deixo a nossos psicanalistas, magos,
xamãs, etc, a descoberta destas neuroses...
Quero aqui pensar na Antropologia como construída a partir da
especificidade da relação entre o pesquisador que investiga um objeto similar
a ele mesmo e do investigado que interage com o pesquisador, já que "o
objeto antropológico é da mesma natureza que o sujeito..." (LAPLANTINE,
1988, p. 91 apud GROSSI, 1992, p. 8).

E prossegue:

[...] Todo mundo já disse mas nunca é demais lembrar que só se encontra o outro, encontrando a si mesmo. Os relatos que serão feitos aqui nos falam de que forma esta auto-busca influiu na interpretação que cada um fez de seu objeto. Penso que não foi o acaso que levou cada um de nós a seguir uma trilha diferente, pois na verdade cada caminho reflete a forma individual e subjetiva do encontro de si mesmo a partir do encontro com o outro (GROSSI, 1992, p. 15-16).

o que você acredita que seja(m) o(s) armário(s); especificamente, quais sentimentos predominam em você sobre o(s) armário(s); você experenciou alguma situação ou algumas situações de saída do(s) armário(s); você julga estar plenamente "fora do(s) armário(s)"; como você encara esta situação de plenitude ou de incompletude em relação à estrutura $\operatorname{do}(\mathrm{s})$ armário(s), foram as perguntas, para além dos dados classificatórios das entrevistadas, que constituíram nosso programa de entrevista.

${ }^{7}$ A pesquisa em tela foi aprovada pelo Comitê de Ética em Pesquisa (CEP) da Universidade Federal de Alfenas (UNIFAL-MG). As duas participantes, mulheres lésbicas, foram convidadas a dar entrevista após assinarem o Termo de Consentimento Livre e Esclarecido (TCLE) e terem todas as suas dúvidas sanadas no que concernia aos procedimentos da pesquisa.

CSOnline - Revista Eletrônica de Ciências Sociais, Juiz de Fora, n. 23 (2017), pp. 327- 343 
Assim, esperamos, dissolvidos alguns dos mitos da disciplina antropológica, como o do "cientista neutro e assexuado", e, uma vez assumida a "'emergência' da subjetividade" como constituidora do objeto de conhecimento, afirmamos que nossas escolhas de pesquisa e o olhar interpretativo que foi dado às narrativas, como discutido por Grossi (1992) em seu texto "Na busca do 'outro' encontra-se a 'si mesmo'", estão por ela (especialmente pela subjetividade de uma das autoras desta investigação) implicados.

Isto posto, esta seção tem como eixo central a reflexão acerca de trajetórias de mulheres lésbicas em relação às suas saídas do(s) armário(s). Outros elementos importantes que perpassam as lesbianidades estão, como se verá a seguir, presentes nas narrativas construídas. No entanto, por não se apresentarem em conexão direta com a questão do(s) armário(s), é importante dizer que esses elementos não foram por nós problematizados, por não serem nosso foco aqui. Fragmentos de falas são apresentadas a seguir.

\section{1. Maria}

Entrevistadora: Você experenciou alguma situação ou algumas situações de saída do(s) armário(s)?

Maria: Eu não sei o termo, se sair do armário, se eu passei por isso. Porque normalmente a pessoa imagina o gay que se assume em casa, o gay que pode levar o namorado em casa. Isso, acho que popularmente, é sair do armário: assumir-se gay para a sociedade é poder andar de mãos dadas na rua com seu namorado. Então, [respondendo à pergunta], não. Mas é que aqui eu não tenho armário. E, na minha cidade, não é que eu não tenha armário, eu acho assim: eu sou fora do armário. [...] Isso que a minha mãe falou: seja gay pra lá $[\ldots]$.

E: E você considera que - uma vez que você vislumbra a ocorrência desse momento [de comunicar explicitamente sua lesbianidade para seus pais], que mais cedo ou mais tarde, ele vai acontecer - você considera esse momento como uma saída do armário? Você acha que ele é um dos principais marcos de saída do armário?

R: Sim, eu acho que sim. Porque, por exemplo, a Ana [ex-namorada da entrevistada] considera que ela é fora do armário, porque ela se assumiu pros pais. Mas, ao mesmo tempo, mantém as aparências. Eu não mantenho as aparências e não sou assumida pros meus pais. Tipo assim, eu sou assumida pra sociedade, mas não sou assumida pros meus pais. Lá é o contrário [com a ex-namorada em questão]: ela é assumida pros pais, mas não é assumida pra sociedade. [...] É só uma analogia que eu faço, porque essa questão da saída do armário, tanto é que não só por mim mas por muita gente, é a questão de não ter tido namorada fixa aqui. Sabe? Pra poder chegar e falar assim: eu namoro. Porque a Ana só falou porque ela namorou a namoradinha dela lá mais de um ano.

E: Então, você acha assim que o namoro é uma situação que ele propulsiona uma saída do armário?

R: Sim, eu acho que sim. Eu não diria crucial, mas acho que a situação vai ter forçando. [...] E, tipo assim, é uma mentira que não precisa: "ah, minha 
amiga!". E, tipo, a tranquilidade de você poder falar: "ah, vou sair com a Larissa, e a minha mãe saber quem é a Larissa, que a Larissa é a minha namorada". Sabe? Saber quem é a Larissa e que eu estou com a Larissa. Essa comodidade que os héteros tem, de falar que vai na rua com o João, sabe? $[\ldots]$.

\subsection{Fernanda}

Fernanda: [...] Porque assim na minha casa eu já sou assumida já faz um tempo. Eu passei por alguns problemas iniciais, mas, agora, a situação é muito tranquila: minha namorada frequenta minha casa como minha namorada. Eu não apresento ela pra minha família como minha amiga. Só que na casa dela é diferente. A gente tem essa noção de que os pais delas sabem, mas, por conta de uma série de acontecimentos, eles me apresentam como amiga. Eles, de certa forma, me vêem dessa forma. Então, eu frequento a casa dela, em alguns eventos familiares, mas sempre como amiga; e a família dela sabe, tipo, tios, primos... mas a mãe dela não sabe, ou, pelo menos, não assume que sabe. E aí é complicado, porque, por mais que eu seja assumida (e a nossa cidade é uma cidade muito pequena, e a cidade inteira saiba que eu sou lésbica, porque eu me assumi desde cedo), eu acabo que ficando parcialmente dentro do armário, porque em alguns momentos eu não posso me assumir, eu não posso me afirmar por conta dela [...].

Entrevistadora: E o que você acredita que seja(m) o(s) armário(s)?

Eu acho que o armário é essa ausência de afirmação ou essa possibilidade de afirmação, sabe? Como eu te falei, eu posso não "tá" dentro do armário em diversas dimensões da minha vida, mas, em uma situação específica, eu não posso sair do armário. E é uma questão muito problemática pra mim, porque obviamente eu tenho receio de alguém chegar na família da minha namorada e falar isso, porque todo mundo sabe, na minha cidade, eu nunca escondi... Só que isso pra ela é um problema, pra família dela é um problema. Então, como é que eu lido com isso? No meu relacionamento com a família dela, eu tenho que "tá" dentro do armário. Eu não posso simplesmente chegar lá e falar: "Eu sou lésbica!", por mais que nas outras esferas da minha vida eu lide bem com essa situação e, de cara, já me afirme. [...] Então eu lido com essa situação muito assim: eu não acho que se você sair do armário em alguma dimensão da sua vida, automaticamente você vai ter saído em todas [...].

E: Você julga estar plenamente "fora do(s) armário(s)"?

Não, e não é por falta de vontade. Mas é por uma questão de entender que as pessoas são diferentes, que os processos das pessoas são diferentes, e por entender que, o fato de eu não poder me assumir na situação em relação à família da minha namorada, não é uma questão simplesmente relacionada à minha sogra ou ao meu sogro, porque elas são pessoas boas ou pessoas ruins. Mas porque são pessoas muito religiosas, são pessoas que tiveram uma outra experiência de vida. "Pros" meus pais, que são muito novos, eu acho que é mais fácil eles entenderem essas coisas do que "pras" pessoas mais velhas, que tiveram outras vivências, que são pessoas muito religiosas. Mas é complicado porque, em diversas situações, eu já me peguei pensando se um dia eu vou poder falar abertamente disso com eles. E, obviamente, eu tenho medo disso não acontecer. É difícil a situação de você não poder falar, de você ser apresentada como amiga... É muito difícil. Mas é uma situação que hoje eu tenho consciência que é uma situação que eu tenho que passar. Que eu aceito por entender e por gostar muito da minha namorada. [...] É muito difícil você viver assim, você não poder viver a sua vida, não poder fazer certas coisas que você gostaria de fazer e não poder a partir de uma escolha que não é sua, que não depende de você, que depende de outras pessoas. E você não tem o direito de fazer a pessoa escolher entre você e a situação, sabe? Não é uma escolha minha e eu não tenho o direito de passar por cima disso. Só que é difícil porque tem horas que a gente fica: "nossa, eu tive tanto 
trabalho pra me assumir, pra me afirmar dentro de casa - hoje em dia tenho uma situação tranquila em relação a isso -, mas, ainda assim, tenho que me esconder porque minha namorada 'tá' dentro do armário". Então eu considero muito isso: que eu "tô" parcialmente dentro do armário, sabe?

É possível perceber, a partir das trajetórias de mulheres lésbicas com relação ao(s) armário(s), condensadas por meio dos excertos supra-referenciados, a marcada presença do(s) armário(s), "como um dispositivo de regulação da vida de gays e lésbicas que concerne, também, aos heterossexuais e seus privilégios de visibilidade e hegemonia de valores" (SEDGWICK, 2007, p. 19), como afirma, de saída, Eve Kosofsky Sedgwick em seu texto "A epistemologia do armário".

O cerne da argumentação da autora em comento encontra-se na sua leitura de que os eventos estadunidenses de 1969 (Revolta de Stonewall) pouco ou quase nada contribuíram para minar os "armários", como à primeira vista uma leitura equivocada far-nos-ia supor. Ainda que mudanças importantes tenham ocorrido (e não se pode negá-las), no fundo, esse dispositivo cultural, valorativo, identitário e epistêmico, fora, em verdade, escassamente desestabilizado, estando longe de se poder pensá-lo em seu estilhaçamento. Antes, mais correto, para essa poeta e crítica literária, poder-se-ia pensar em sua acentuação, e não em seu envelhecimento. "Uma estrutura narrativa tão elástica e produtiva não afrouxará facilmente seu controle sobre importantes formas de significação social" (SEDGWICK, 2007, p. 21).

Portanto, ao contrário do que se poderia pensar, a história de Fernanda, exemplarmente, evidencia que por mais "assumidamente" lésbica que se possa ser (como para os próprios membros da família mais imediata, como para os pais), é muito difícil (ou, talvez, impossível) não estar no armário com alguém. Como ela conta, ainda que em casa ela já seja "assumida" e isto já há algum tempo e que sua namorada seja apresentada enquanto tal neste ambiente, em alguns eventos organizados por familiares da sua namorada, novos armários são como que construídos, bem como novos esquemas e demandas de sigilo ou exposição são demandados a ela e à namorada enquanto mulheres lésbicas - bem como àqueles que se encontram dentro da ordem heterossexual, como os seus sogros (pessoas heterossexuais). Assim, ainda que a entrevistada em questão tenha deliberadamente escolhido comunicar sua lesbianidade e tenha tido, como nos diz, inclusive, muito trabalho para se "assumir" em casa, vemos que escolher deliberadamente entre ficar ou voltar para o armário em algum ou em todos os segmentos de sua vida, em última instância, independerá, inúmeras vezes (ou talvez em todas elas) dela própria, o que confirma o quanto a identidade lésbica in casu 
é eivada por torções e fora do centro. Pode-se dizer então e conjuntamente com Sedgwick (2007, p. 40) que "[a]ssumir-se não acaba com a relação de ninguém com o armário, inclusive, de maneira turbulenta com o armário do outro".

Assim, tanto a história de Fernanda quanto a de Maria evidenciam que elas estão assoladas por "[u]ma incoerência relacionada, posta nos termos altissonantes da distinção entre público e privado", que, reforçando, como coloca Sedgwick (2007, p. 25, grifo da autora) "assola o espaço contemporâneo do ser gay". Maria, ao contar que sua ex-namorada, Ana, é "assumida" para os pais e não para a sociedade - por manter as "aparências" - e ela própria, Maria, ao contrário de Ana, ser "assumida" para a sociedade e não para os pais, deixa marcante esse "[...] torturante sistema de duplos vínculos, [que] oprim[e] sistematicamente as pessoas, identidades e atos gays [lésbicos, bissexuais, pansexuais, etc.] ao solapar, por meio de limitações contrárias ao discurso, as bases de sua própria existência" (SEDGWICK, 2007, p. 26). A história destas duas jovens mulheres, compatível, em alguma medida, com os dados da literatura, mostra uma

\begin{abstract}
relação distintivamente indicativa entre homossexualidade e mapeamentos mais amplos do segredo e da revelação, do privado e do público, que eram e são criticamente problemáticos para as estruturas econômicas, sexuais e de gênero da cultura heterossexista como um todo; mapeamentos cuja incoerência capacitadora, mas perigosa, foi condensada de maneira opressiva e duradoura em certas figuras da homossexualidade. "O armário" e "a saída do armário", ou "assumir-se", agora expressões quase comuns para o potente cruzamento e recruzamento de quase todas as linhas de representação politicamente carregadas, têm sido as mais magnéticas e ameaçadoras dessas figuras (SEDGWICK, 2007, p. 26).
\end{abstract}

\title{
3 Considerações finais: "saindo" do armário?
}

A partir das trajetórias dessas duas mulheres, e uma vez destacáveis as compatibilidades daquelas com alguns dados da literatura que acionamos, foram reafirmadas as danosas contradições do(s) armário(s) e os pares dentro/ fora, segredo/ revelação, público/ privado, e, em última instância, conhecimento/ ignorância - dentre outros básicos para a cultura ocidental -, com os quais ele(s) está(ão) comprometido(s). Com isso, não se está dizendo (ou se querendo dizer) que mudanças substanciais para as pessoas heterodissidentes não se deram e isto tudo em torno e "fora" do(s) armário(s). Não estamos aqui, como adverte Sedgwick (2007, p. 23) "exalta[ndo] o próprio armário, 
ainda que apenas por omissão; [...] apresenta[ndo] como inevitáveis [...], de alguma forma, suas exigências, deformações, a impotência que causa a pura e simples dor".

Assim, foi possível evidenciar, antes, e mesmo que correndo riscos ao fazê-lo (ao se enfatizar a continuidade e centralidade do armário na cultura ocidental), que a presunção da heterossexualidade e o fenômeno que ela ilustraria - a heterossexualidade como instituição -, seriam elasticamente gerais porque seriam coletivos. Aquela suposição é um estado do grupo, que se repete formativamente nos indivíduos porque se impõe a eles. Assim, essa presença formadora, por estar no todo, espraiar-se-ia sobre as partes individuais (e não o contrário), sendo uma característica não apenas nas vidas de pessoas LGBT's, mas também na vida de pessoas ditas heterossexuais, ainda que seja mais fundamental para as primeiras.

\begin{abstract}
Mesmo num nível individual, até entre as pessoas mais assumidamente gays há pouquíssimas que não estejam no armário com alguém que seja pessoal, econômica ou institucionalmente importante para elas. Além disso, a elasticidade mortífera da presunção heterossexista significa que, como Wendy em Peter Pan, as pessoas encontram novos muros que surgem à volta delas até quando cochilam. Cada encontro com uma nova turma de estudantes, para não falar de um novo chefe, assistente social, gerente de banco, senhorio, médico, constrói novos armários cujas leis características de ótica e física exigem, pelo menos da parte de pessoas gays, novos levantamentos, novos cálculos, novos esquemas e demandas de sigilo ou exposição. Mesmo uma pessoa gay assumida lida diariamente com interlocutores que ela não sabe se sabem ou não. É igualmente difícil adivinhar, no caso de cada interlocutor, se, sabendo, considerariam a informação importante. No nível mais básico, tampouco é inexplicável que alguém que queira um emprego, a guarda dos filhos ou direitos de visita, proteção contra violência, contra "terapia", contra estereótipos distorcidos, contra o escrutínio insultuoso, contra a interpretação forçada de seu produto corporal, possa escolher deliberadamente entre ficar ou voltar para o armário em algum ou em todos os segmentos de sua vida (SEGDWICK, 2007, p. 22).
\end{abstract}

Por ser um tipo de opressão manifesta em escala coletiva e institucionalmente corporificada, a força imperativa e coercitiva de uma organização cultural moderna (de origens europeias) heterossexista não pode deixar de ser seu caráter intrínseco, e a prova disso é que ela se afirmará, de forma larga, independentemente da vontade individual, assolando-a, extorquindo-a e deformando-a. "O armário é um lugar contraditório ou impossível, pois ninguém pode estar completamente nele nem se beneficiar da decisão de deixá-lo" (MISKOLCI, 2007, p. 61). Um simples decreto da vontade não pode dissipar facilmente esta que "[...] é a estrutura definidora da opressão gay no século XX" (SEDGWICK, 2007, p. 26), tal a sua extensão e força. 


\section{REFERÊNCIAS}

GROSSI, M. P. Na busca do "outro" encontra-se a "si mesmo". In: (Org.).

Trabalho de campo \& subjetividade. Florianópolis: Cláudia Lago, 1992. p. 7-18.

MISKOLCI, R. Comentário. Cadernos Pagu, Campinas, n. 28, p. 55-63, 2007.

MOMBAÇA, J. Pode um cu mestiço falar? [S.l.]: 2015. Disponível em:

$<$ https://medium.com/@jotamombaca/pode-um-cu-mestico-falare915ed9c61ee\#.wkqw283rt>. Acesso em: 13 jul. 2017.

NOVAES, S. C. Introdução. In: de si através dos outros. Edusp, 1993. p. 19-34.

. Jogo de espelhos: imagens da representação

OLIVEIRA, R. M. de; DINIZ, Débora. Materiais didáticos escolares e injustiça epistêmica. Educação e Realidade, Porto Alegre, v. 39, n. 1, p. 241-256, 2014.

SEDGWICK, E. K. A epistemologia do armário. Cadernos Pagu, Campinas, n. 28, p. 19-54, 2007.

SILVA, T. de M. G. "Você tem que ficar manobrando as coisas": lesbianidades, violências cotidianas e possibilidades de resistência. 2015. 117 f.. Dissertação (Mestrado em Antropologia Social) - Faculdade de Ciências Sociais, Universidade Federal de Goiás, Goiânia, 2015.

WITTIG, M. O pensamento heterossexual. In: O pensamento heterossexual e outros ensaios. Barcelona: Egales Editorial, 2005. p. 45-58. 